Journal of

Arid

ELSEVIER

Journal of Arid Environments 62 (2005) 177-197

Environments

www.elsevier.com/locate/jnlabr/yjare

\title{
Agricultural, architectural and archaeological evidence for the role and ecological adaptation of a scattered mountain oasis in Oman
}

\author{
S. Siebert ${ }^{\mathrm{a}}$, J. Häser ${ }^{\mathrm{b}}$, M. Nagieb ${ }^{\mathrm{a}}$, L. Korn ${ }^{\mathrm{c}}$, A. Buerkert ${ }^{\mathrm{a}, *}$ \\ ${ }^{a}$ Institute of Crop Science, University of Kassel, Steinstr. 19, D-37213 Witzenhausen, Berlin, Germany \\ ${ }^{\mathrm{b}}$ Deutsches Archäologisches Institut, Orient-Abteilung, Podbielskiallee 69-71, D-14195 Berlin, Germany \\ ${ }^{\mathrm{c}}$ History of Islamic Art and Archaeology, An der Universität 11, D-96045 Bamberg, Germany
}

Received 19 December 2003; received in revised form 5 August 2004; accepted 14 September 2004

Available online 12 January 2005

\begin{abstract}
The recent discovery of the monumental 5000 years old tower tombs on top of the up to $1850 \mathrm{~m}$ high Shir plateau has raised numerous questions about the economic and infrastructural basis of the agro-pastoral-piscicultural society which likely has constructed them. The scattered oasis settlement of Maqta, situated just below the towers in a rugged desert environment has therefore been studied from 2001 to 2003 to understand its prehistoric and present role along the ancient trade route which connected the inner-Omani Sharqiya across the southern Hajar mountains with the ocean port of Tiwi. Maqta consists of a central area with 59 buildings and 12 scattered temporary settlements comprising a total of about 200 semi-nomadic inhabitants and next to 900 sheep and goats. The 22 small springs with a flow rate between 5 and $1212-1 \mathrm{~h}^{-1}$ are watering 16 terrace systems totaling 4.5 ha of which 2.9 ha are planted to date palms (Phoenix dactylifera L.), 0.4 ha to wheat landraces (Triticum durum and Triticum aestivum) during the cooler winter months, 0.4 are left fallow and $0.8 \mathrm{~h}$ are abandoned. During a pronounced drought period from 2001 to 2003, the springs' flow rate declined between $38 \%$ and $72 \%$. Most of the recent buildings of the central housing area were found empty or used as temporary stores by the agro-pastoral population watching their flocks on the surrounding dry mountains. There is no indication that there ever was a settlement older than the present one. A number of Hafit (3100-2700 BC) and Umm an-Nar (2700-2000 BC) tombs just above the central housing area and further along one of the trade
\end{abstract}

\footnotetext{
*Corresponding author.

E-mail address: buerkert@uni-kassel.de (A. Buerkert).
} 
routes to the coast are the only indication of an old pastoral landuse in Maqta territory where oasis agriculture may have entered only well after 1000 AD. With this little evidence of existence during the $3 \mathrm{rd}$ millennium $\mathrm{BC}$, Maqta is unlikely to have played any major role favouring the construction of the nearby monumental Shir tower tombs other than providing water for herders and their flocks, early migrant traders or tower tomb constructors.

(C) 2004 Elsevier Ltd. All rights reserved.

Keywords: Ecological agriculture; Landscape archaeology; Oasis agriculture; Vernacular rural architecture; Water scarcity

\section{Introduction}

The Jabal Bani Jabir in the southern Hajar mountain range of northern Oman represents one of the driest climates on earth with a potential evapo-transpiration of more than $2500 \mathrm{~mm}$ and an average annual precipitation of less than $75 \mathrm{~mm}$. Whereas a companion paper describes the current status and development history of oasis agriculture in a typical composite settlement of the northern Hajar mountains (Nagieb et al., 2004), this study focuses on the ecological adaptation of a scattered agro-pastoral oasis further south. This area is topographically important as the up to $1850 \mathrm{~m}$ high Shir plateau divides the coastal zone of the Arabian Sea from the innerOmani Sharqiya. The extended Shir plateau is also the origin of four major drainage systems, Wadi Tiwi and Wadi Shab to the east, Wadi Bani Khalid to the south, and Wadi Khabbah to the north-west. Given the lower water availability on the western side of the Jabal Bani Jabir compared to their water-rich eastern side (Korn et al., 2004), terraced land is very scarce in the former area. Besides, perennial cultivation of date palm (Phoenix dactylifera L.), annual crop production plays a less important role on the eastern side. Similar to the northern Hajar range, the irrigation infrastructure needed for any agricultural production in this area is based on ainiaflaj (sing. falaj) systems, referring to canals that convey water from a spring at the foot of a mountain to agricultural fields. Settlements typically consist of either only semi-nomadic pastoralists or an agro-pastoral community cultivating a number of small and widely scattered terrace systems with a field size between 2 and $160 \mathrm{~m}^{2}$. Most of these are squeezed between cliffs into rugged mountain escarpments and headed each by a tiny spring. Below the spring, four types of agricultural production are positioned like onion skins. The most water demanding date palms are immediately adjacent to the spring or a water collection basin. These are followed by fields planted to Omani wheat landraces (Triticum durum and Triticum aestivum; AlMaskri et al., 2003) during the cooler winter months and left fallow the rest of the year, fields which are used for fodder production and finally terraced fallow plots which are only cropped in years of abundant rainfall. Except for date palms no cultivation occurs during the hot summer months.

Archaeologically important in this region are the so-called 'tower tombs' on the top of the Shir plateau (Fig. 1 and Photo 1). They were discovered from the air in 1977, presented to the public in 1991 by Paolo Costa (Yule and Weisgerber, 1996) 


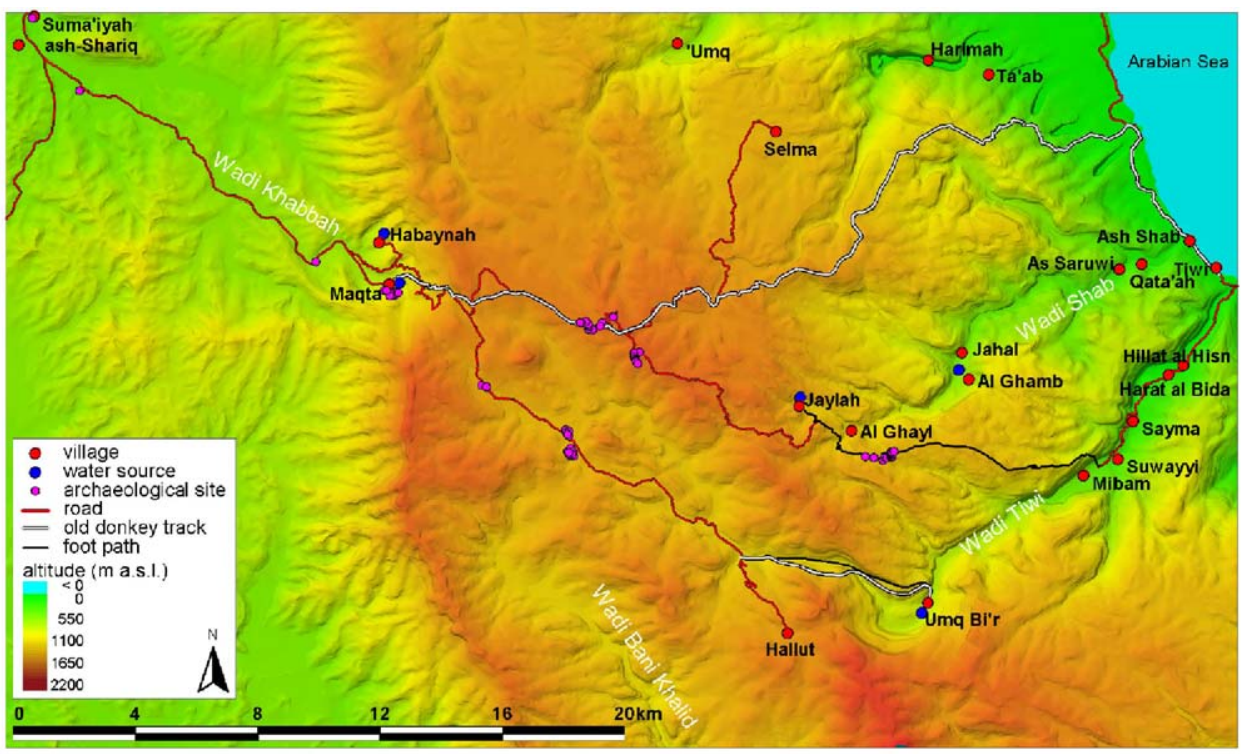

Fig. 1. Three-dimensional map of the study area reaching from the Arabian Sea in the east across the Jabal Bani Jabir mountains of central Oman to the Wadi Khabbah in the west.

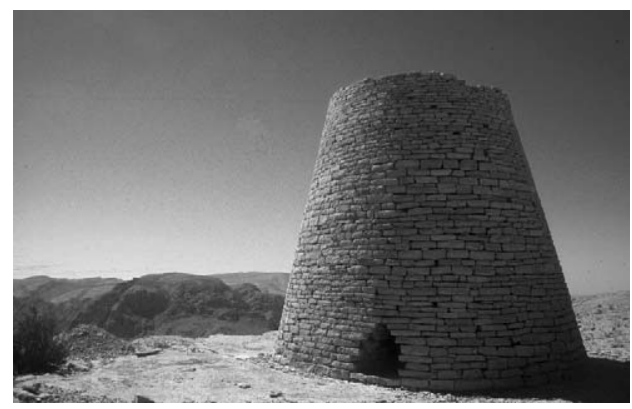

Photo 1. Tower tomb Sh1 on the Shir plateau.

and published for the first time by Yule (1992). In 1995, these tombs were examined more thoroughly by Yule and Weisgerber (1996, 1998). A total of 59 tombs were registered in an area of several square kilometers and three of them were excavated. Five different building types of tombs were observed which all resembled in form and manner of building graves of the Hafit or Umm an-Nar period (3100-2000 BC; Table 1). However, no finds were discovered to confirm this date. Instead, some pottery sherds were found which were dated to the early Iron Age (1100-600 BC) probably belonging to secondary burials.

In search for a settlement, which belongs to the tombs on the Shir plateau, the mountain oasis of Maqta (Fig. 1) was first surveyed by Yule and Weisgerber (1998) 
Table 1

Archaeological and historic time periods in Oman

\begin{tabular}{ll}
\hline Time period & Duration \\
\hline Hafit & $3100-2700 \mathrm{BC}^{\mathrm{a}}$ \\
Umm an-Nar & $2700-2000 \mathrm{BC}$ \\
Wadi Suq & $2000-1300 \mathrm{BC}$ \\
Iron Age I & $1300-1100 \mathrm{BC}$ \\
Iron Age II & $1100-600 \mathrm{BC}$ \\
Iron Age III & $600-300 \mathrm{BC}$ \\
Late Iron Age (Samad) & $300 \mathrm{BC}-630 \mathrm{AD}$ \\
Early Islamic & $630-1055 \mathrm{AD}$ \\
Middle Islamic & $1055-1500 \mathrm{AD}$ \\
Late Islamic & $1500-1970 \mathrm{AD}$ \\
Recent & $1970-$ today \\
\hline
\end{tabular}

${ }^{\mathrm{a}}$ Before the birth of Christ.

${ }^{\mathrm{b}}$ After the birth of Christ.

in 1995. During a 1 day visit they discovered several Hafit tombs (Maqt1, Maqt2), two tombs of unknown date (Maqt3), a $30 \mathrm{~m}$ long wall (Maqt4), that was interpreted as an Iron Age fortification, as well as several Iron Age hut tombs and some Umm an-Nar houses (Maqt5) in the sedimentation depression above the settlement of Maqta (Fig. 2).

Following Wadi Khabbah into the direction of the inland, the same group of archaeologists discovered several triliths (Sha1, Sha3), stone alignments of unknown function, and several Hafit-type tombs (Sha2, Sha5, Sha8) at the village of ashShariq (Fig. 1). A sherd of a typical bottle of the Samad period (300-900 BC) showed that this area was also used in that period. Not far from ash-Shariq is the oasis of Suma'iyah where the most prominent archaeological site is an early Iron Age (1100-600 BC) fortress on top of the Qarn Suwaich (Ism1). The ruins of houses on artificial terraces are still visible and a lot of very coarse domestic pottery is scattered between them. Some Hafit-type tombs (Ism2) are also visible on the mountain crest ending at the edge of the fortress.

Most archaeological investigations north of the Shir plateau are focused on the coast (Biagi, 1988; Ibrahim and ElMahi, 2000). Only a single survey between ashShab and Tiwi as well as in Wadi Tiwi so far considered the hinterland and the likely connection between coast and inland (Fig. 1; Häser and Schreiber, 2003; Schreiber and Häser, 2004; Korn et al., 2004). This survey provided evidence for a continuous occupation of Tiwi from the 5th millennium BC to modern times, whereas Wadi Tiwi was only settled from the 9 th/10th century AD to modern times. Nevertheless, the position of Hafit-type tombs on very prominent places along the coast and at the entrance to Wadi Tiwi suggested that they served as markers for inland routes which might have been in existence by the late 4th/early 3rd millennium BC.

This interdisciplinary study between agricultural scientists, archaeologists and orientalists had several goals. Firstly to analyse the agricultural structure of one of the scattered agro-pastoral settlements in the Jabal Bani Jabir as a function of 


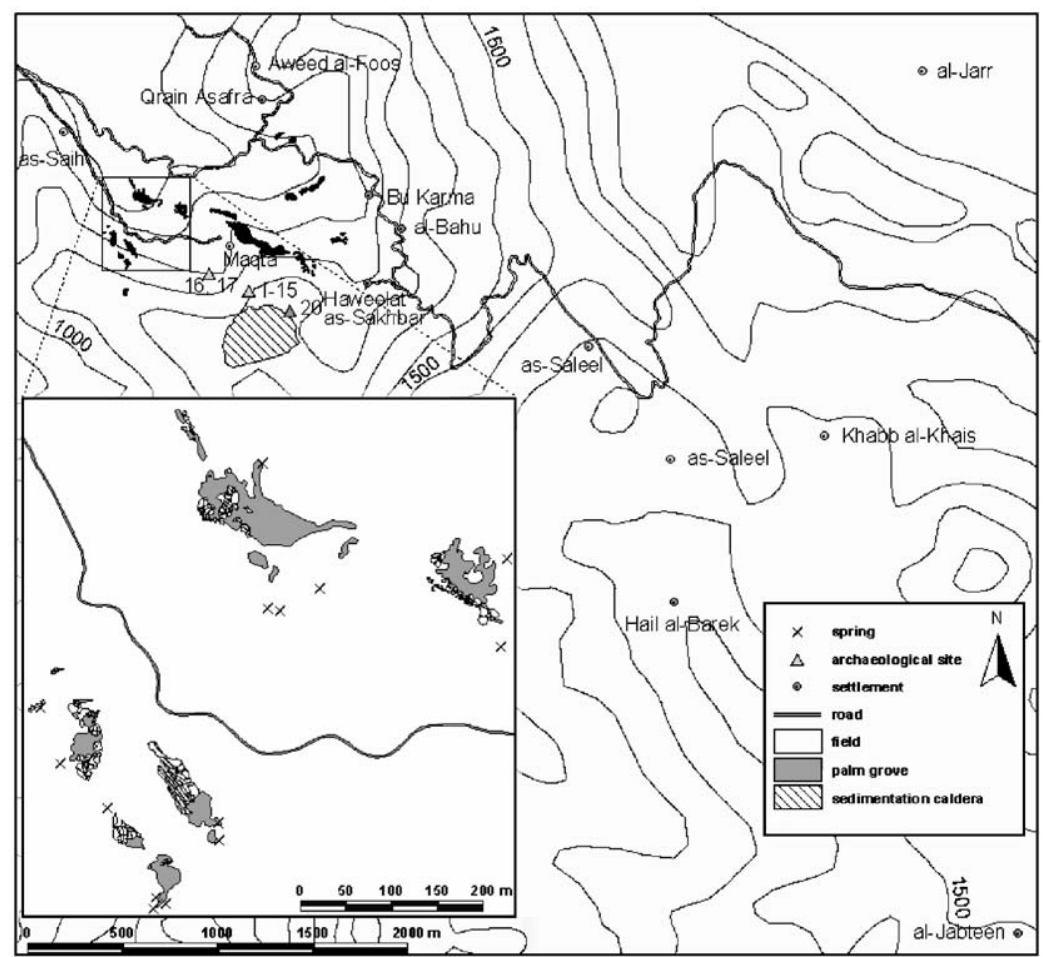

Fig. 2. GIS-based map of the Maqta territory in Oman with the terrace systems, the central housing area, the dispersed settlements, the natural grazing basin and the major archaeological sites.

topography and water availability. Secondly to describe the composition of the central housing area and to develop a likely settlement history based on the available archaeological finds. In a larger context this study thirdly aimed at a partial understanding of the role mountain oases in northern Oman may have played as an economic and cultural link between coastal and inland areas.

\section{Methodology}

\subsection{Experimental area and bio-physical measurements}

The study area comprised the agro-pastoral, communal territory of Maqta village in the Wadi Khabbah of the Jabal Bani Jabir mountains of Central Oman. This territory is divided into a central village area $\left(59.00^{\circ} \mathrm{E}, 22.83^{\circ} \mathrm{N} ; 1050 \mathrm{~m}\right.$ asl $)$ with 73 houses, an agricultural area comprising 16 small terrace systems and 12 scattered temporary settlements within the vast rocky grazing area and inhabited by an agropastoral population which identifies itself as inhabitants of Maqta. The methods used for the agricultural part of the study closely followed those described by Nagieb 
et al. (2004). First, the topography of the rugged surrounding mountains was digitized from Russian military maps (1:100,000, Joint Stock Company SK-IMPEX, Moscow, Russia) with 40-m altitude lines. Subsequently, all major features governing the territory of Maqta were mapped using a differential Global Positioning System (GPS; Trimble Pathfinder, Sunnyvale, CA, USA) with decimeter precision. Those features comprised the position of all major villages between Maqta and the coastal town of Tiwi, the modern dirt road connecting most villages and the two major, traditional trade routes to the coastal zone of Tiwi and the position of springs on the Jabal Bani Jabir between the Wadi Khabbah and the Arabian Sea. For the territory of Maqta settlements, the terraces systems with their total of 22 springs, the position of date palms (separately for young and adult individuals) and the size of wheat fields cultivated in early 2002 and 2003 were mapped. The position of a major sedimentation depression above Maqta (1160 m asl; Photo 2) of $500 \mathrm{~m} \times 300 \mathrm{~m}$ in size was also entered. It comprised at its northern bench a number of major archaeological features such as tombs and at the eastern end an ancient falaj. The basis of this falaj contained some charcoal that was used for ${ }^{14} \mathrm{C}$-dating using accelerated mass spectrometry at the Leibniz Laboratory of Age Determination and Isotope Research in Kiel, Germany.

To estimate the agricultural production of the oasis, grain yield and total dry matter of wheat were measured in 10 representative fields and multiplied by the area harvested. Total date palm yield was estimated through farmers' records for individual trees and multiplied by the total number of adult date palms.

To obtain the amount of water available over time between March 2001 and March 2003, repeated outflow measurements of all springs were taken with a handoperated barrel system. During the entire period no measurable rainfall occurred. The regular occurrence of such droughts in Oman has been confirmed by farmers'

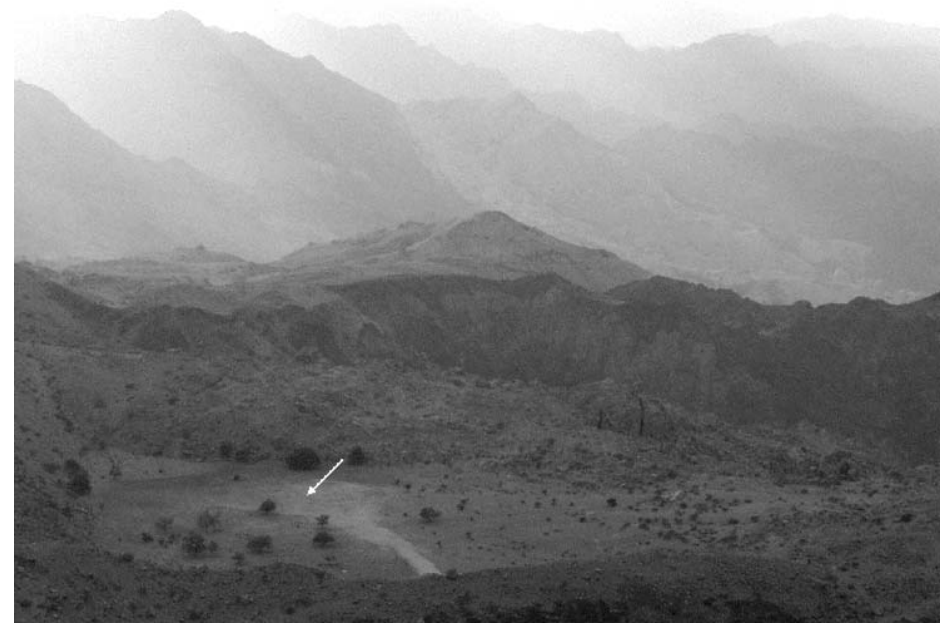

Photo 2. Sedimentation depression above Maqta from the north. The white arrow indicates the location of the soil profile taken for pollen analysis. 
oral records and the 110-year weather records from Seeb Airport in Muscat (FAO, 2001). In November 2002 and January 2003, selected springs were also sampled to determine the approximate age of the stored water using its tritium $/{ }^{3}$ helium ratio and concentration of the anthropogenic trace gases sulphurhexafluoride and chlorfluorcarbohydrates according to methods described in detail by Aeschbach-Hertig et al. (1998) and Beyerle et al. (1999). The purpose of these water measurements in the context of this paper was to compare the 'elasticity' of water flow during the extended period of drought to data from the Balad Seet oasis in the Northern Hajar range. This comparison was meant to provide some indication of the degree of water scarcity one might expect during drought periods and help to explain the likely adaptation strategies to this constraint by the agro-pastoral community. In October 2002, a soil pit was dug into one of the typical terrace soils cropped to wheat and a lacquer peel technique (modified after Hähnel, 1961) was used to prepare a profile (Photo 3).

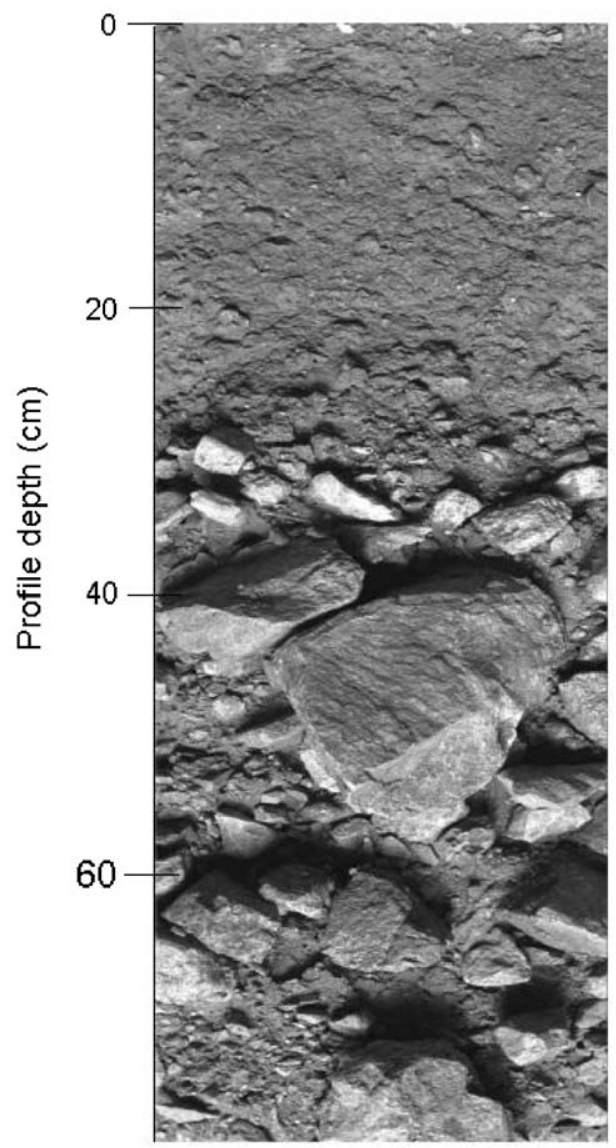

Photo 3. Profile of a typical man-made terrace soil at Maqta (Oman). 


\subsection{Estimation of agricultural production and carrying capacity}

In contrast to a similar study in the Northern Oman mountains (Nagieb et al., 2004), only a simplified analysis of the ecological carrying capacity of the Maqta territory was conducted. Since the road construction in 1985, major amounts of drinking water for humans and animals as well as fodder grasses are being transported regularly into the area. This and government allowances paid to the semi-pastoral farmers living in the Maqta territory has led to a rise of the carrying capacity far beyond that determined by the ecological resource base. The estimation of the traditional ecological carrying capacity was based on a typical drought scenario when the available water is concentrated on the date palm groves and therefore no annual crops are cultivated. Similar to the approach described by Nagieb et al. (2004), the underlying assumptions of the analysis were:

(1) The water outflow of the springs in the Maqta territory during prolonged drought periods is similar to the one measured during 2001-2003.

(2) Date yields and energy levels from today's local palms genotypes are similar to those prior to 1970 . Present-day date yield of $25 \mathrm{~kg} \mathrm{DM}_{\text {tree }}^{-1}$ year $^{-1}$ are in close agreement with data reported from Oman prior to modernization (FAO Stat, 2003).

(3) Goats and sheep are fed entirely by natural grazing of the mountain pastures and the meat harvested from the flock is similar to today's conditions.

(4) The energy contained in the dates and meat can be taken from the literature (George, 1987).

To compare the agro-ecological conditions of Maqta territory to those elsewhere in Northern Oman, its palm grove area, total size of terraced fields, number of inhabitants and the available water was compared to those of the core oasis of Balad Seet in the northern Hajar mountains and to Wadi Tiwi on the eastern side of the Jabal Bani Jabir.

\subsection{Architectural data}

The built substance of the central housing area of Maqta was recorded with balloon-based aerial photographs (Buerkert et al., 1996) followed by a ground survey. The vertical images were used to draw a preliminary ground plan of the village that was verified on the ground house by house. Subsequently, the preliminary map was refined by detailed control measures. Notes on building conditions, access, functions and current use of buildings were taken. Additional information on the functions of buildings was gathered through informal interviews with inhabitants.

\subsection{Archaeological setting}

Given the scattered nature of the settlements, the overall poor find situation and the time available, all data were collected in two 1-day surveys conducted by foot. 
The survey in the surroundings of Maqta was based on aerial photographs (OM8173-110-190 and OM81-73-110-191 at the scale 1:20,000) taken in 1981 by the National Survey Authority of Oman. The positions of all identified archaeological sites were registered by GPS. The tombs at the edge of the sedimentation depression above Maqta were photographed from a height of about $100 \mathrm{~m}$ using the same balloon technique. Also, a group of newly discovered tombs between Mibam and Jaylah was registered, examined and photographed. The already-mentioned tombs on the Shir plateau were not the subject of the survey since these have already been described in detail by Yule and Weisgerber (1998). However, they were visited several times to allow typological comparisons. All finds of pottery sherds were classified by ware type, shape and dimension. Subsequently, the sherds were dated according to an existing pottery typology.

\section{Results}

\subsection{Traditional trading infrastructure, bio-physical setting and agricultural carrying capacity}

According to local oral records, the probably millenia-old, $40 \mathrm{~km}$ long and fully developed donkey trade route from Maqta to Tiwi (Fig. 1) was not only used to regularly exchange wheat from the Sharqiya against dried fish for everyday consumption from the coast but also to import large quantities of dried anchovies (Engraulidae). These were reportedly applied as a phosphorus (P) fertilizer annually at a rate of $1-2 \mathrm{~kg}$ dry matter per palm tree which at an assumed $\mathrm{P}$ concentration of $35 \mathrm{~g} \mathrm{~kg}^{-1}$ would correspond to about $53 \mathrm{~g} \mathrm{P}$ per year and thus be equivalent to the $\mathrm{P}$ uptake of $80 \mathrm{~kg}$ dates. The equally ancient footpath between Jaylah and Mibam in contrast seems to have served as a shortcut for personal visits and the transport of minor goods between the extended families divided by the Jabal Bani Jabir mountain range. A recent evidence of these old family ties is the fact that Habaynah, the village next to Maqta on the western side of the Jabal Bani Jabir mountains administratively belongs to the coastal area of Fins on the eastern side of the mountain range north of Tiwi.

In March 2003, the village territory of Maqta comprised approximately 200 agropastoral inhabitants distributed in the central housing area and the 12 scattered settlements. Of the total of 4.5 ha terraced land, 2.9 ha were planted to date palms, in part with an understory production of fodder grasses, 0.4 ha to wheat of the Walidi landrace (Al-Maskri et al., 2003), 0.4 were left fallow and $0.8 \mathrm{~h}$ were abandoned. At this moment the outflow of the different springs varied between 5 and $1212-1 \mathrm{~h}^{-1}$ compared to $18-1 \mathrm{~h}^{-1}(-72 \%)$ and $1928-1 \mathrm{~h}^{-1}(-38 \%)$ for the same springs 2 years earlier. The 2 years of drought had clearly affected the small springs much more than the big ones. During the same period, total spring outflow declined by $46 \%$ from 9.0 to $4.8 \mathrm{~m}^{3} \mathrm{~h}^{-1}$, which corresponds to a $2 \%$ decline per month (Fig. 4). Water age in the measured springs ranged between 2 and 8 years (Luedeling et al., unpublished). As a response to increasing water scarcity, the total area planted to wheat at Maqta 


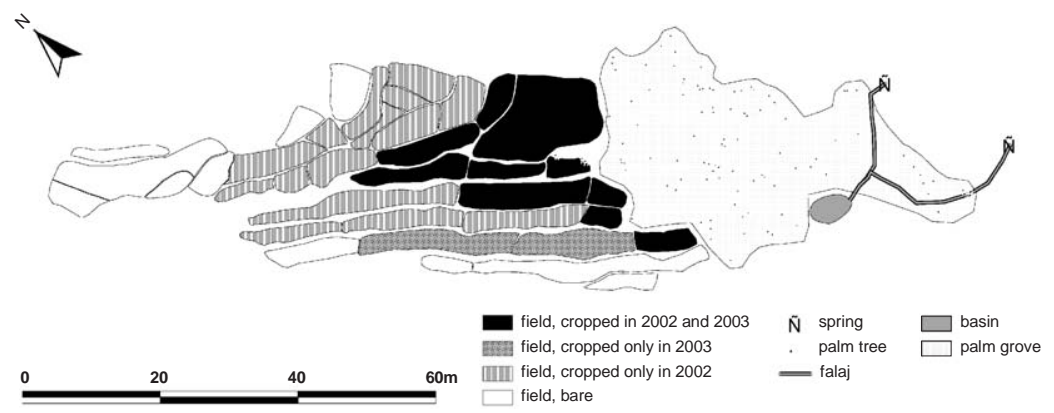

Fig. 3. Map of a typical terrace system (see also Photo 4) of Maqta (Oman) with the spring, position of date palms and the cultivated wheat fields in March 2001 and March 2003 after 2 years of pronounced drought.

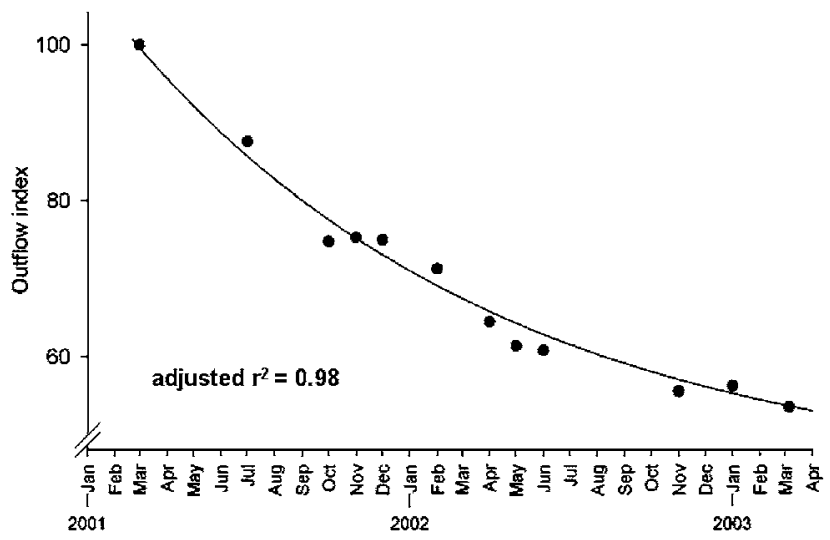

Fig. 4. Total outflow of the 22 springs at Maqta relative to the onset of the measurement period in March 2001. No rainfall was recorded for the 24-month measurement period.

declined from 0.4 ha in early 2001 to less than 0.3 ha 2 years later (Figs. 3 and 4). As the drought progressed in January and February 2003 even many of the planted plots could not be irrigated to maturity but were harvested just after booting as green fodder (Photo 4).

Across all terrace systems, grain yield of wheat varied from 2.4 to $3.5 \mathrm{tha}^{-1}$ with a simultaneous total dry matter production of 11.4 to $12.3 \mathrm{tha}^{-1}$ and little variation as a consequence of decreased water availability. Date yield on the 947 adult palms ranged between 10 and $50 \mathrm{~kg}$ per adult tree and manure addition between $10-40 \mathrm{~kg}$ per tree for palm groves and $10-15 \mathrm{tha}^{-1}$ for wheat fields.

Inspection of the vegetation depression after a 20-mm rainfall in April 2003 revealed a strong germination of fodder grasses and a regular pattern of spontaneously growing indigo (Indigofera tinctoria L.) on about 0.25 ha whose leaves according to farmers records were used locally as a medical tea and sold as a 


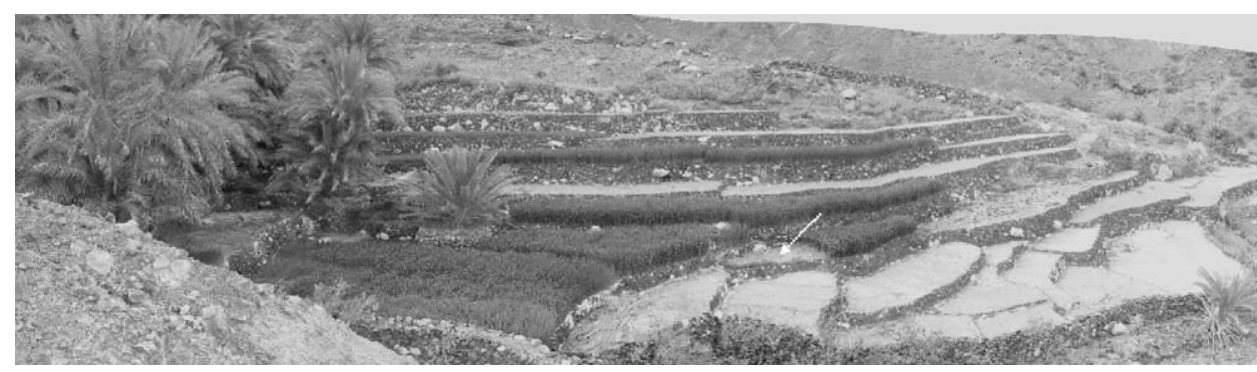

Photo 4. Terrace system at Maqta, Oman (see also Fig. 3) with date palms near the spring (left) and fields planted to winter wheat further right. After a 2-year drought, half of the land has been left fallow due to water scarcity. The white arrow indicates a wheat plot which due to water scarcity was cut prematurely as fodder.

Table 2

Estimated carrying capacity of the scattered mountain oasis of Maqta (Oman) during a drought period ${ }^{\mathrm{a}}$

Agricultural resources and their use

Number of adult date palms

Average date palm yield $\left(\mathrm{kg}(\text { tree } \times \mathrm{yr})^{-1}\right)$

Total date harvest $\left(\mathrm{kg} / \mathrm{yr}^{-1}\right)$

Energy content dates $\left(\mathrm{kJ} \mathrm{kg}^{-1}\right)$

Total energy from dates (MJ)

Energy demand per inhabitant $\left.(\mathrm{kJ} \text { (head } \times \text { day })^{-1}\right)$

Number of adult inhabitants living from dates

Number of small ruminants ${ }^{\mathrm{b}}$

Fraction of animals slaughtered per year

Energy content meat $\left(\mathrm{kJ} \mathrm{kg}^{-1}\right)$

Meat per slaughtered animal $\left(\mathrm{kg} \mathrm{head}^{-1}\right)$

Total energy from meat $\left(\mathrm{MJ} \mathrm{yr}^{-1}\right)$

${ }^{a}$ During a pronounced drought period all water is used to irrigate the palm groves and no annual crops are cultivated.

${ }^{\mathrm{b}}$ Number of goats and sheep kept with current levels of feed supplementation in the Maqta territory. The number of heads under traditional animal husbandry without such levels of external inputs is unknown but should have been substantially lower.

natural dye. The radiocarbon dating suggested a falaj age of $425 \pm 30$ years B.P., but it remains unclear whether the falaj was constructed or renovated at this time.

The calculations of the ecological carrying capacity of the Maqta territory prior to the advent of modern external subsidies indicated that the equivalent of a maximum of 72 adults may have been able to live there from agriculture. For these date production was energy wise much more important than herding on the marginal pastures (Table 2). The comparison of the natural resources of Maqta with the core oasis of Balad Seet and Wadi Tiwi confirmed the marginal status of the former. It was governed by a per capita water availability which at Maqta was only $4 \%$ and an agricultural area that was only $15 \%$ of that at Wadi Tiwi (Table 3). At a similar 
Table 3

Comparison of natural resources and inhabitants in the scattered oasis of Maqta, the core oasis of Balad Seet and the water-rich valley oasis of Wadi Tiwi in Northern Oman

\begin{tabular}{lllll}
\hline Natural resource & Maqta & Balad Seet & Wadi Tiwi & Wadi Tiwi and Tiwi \\
\hline Palm grove area (ha) & 2.9 & 8.8 & 107.0 & 128.2 \\
Terraced fields (ha) & 1.6 & 4.6 & 0 & 3.3 \\
Available water $\left(\mathrm{m}^{3} \mathrm{~d}^{-1}\right)$ & 115 & 601 & 10,000 & 10,000 \\
Number of inhabitants & 200 & 650 & 695 & 2884 \\
Average agricultural area per inhabitant $\left(\mathrm{m}^{2}\right)$ & 225 & 207 & 1540 & 456 \\
Fraction of palm grove area & 0.64 & 0.66 & 1 & 0.98 \\
Cropping intensity in $2002 / 2003$ & 0.66 & 0.85 & 1 & 1 \\
Available water per inhabitant $\left(\mathrm{ld}^{-1}\right)$ & 575 & 925 & 14,388 & 3467 \\
\hline
\end{tabular}

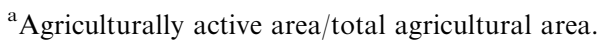

${ }^{\mathrm{b}}$ Total population in 2003 comprising adults and children.

amount of agricultural land per inhabitant, Balad Seet had almost twice as much water as Maqta.

\subsection{Architectural structure}

The central housing area of Maqta has a rather unified structure with respect to coherence of the built area, building types and building techniques. However, there are clear differentiations in each category that allow consistent conclusions about the recent development of the settlement. The overall situation of Maqta within a mountain slope facing north-west implies a rise in ground level of about $10 \mathrm{~m}$ from the open square where the road from Suma'iyah terminates (Fig. 5, between 1 and 2), to the eastern end of the village (24). Some houses are built on a level some meters further up (30-37). The steepest parts of the ascent, marked by the steps between (9) and (18), and south of (6) and (7), form the ramp to the terrace on which the core of the village is placed (Photo 5). The area adjacent to the village to the north, still flat but strewn with large rocks, is occupied by near-circular animal pens.

A clear differentiation can be made between the clustered houses in the eastern part, and the loose structure in the western half of the built area of Maqta. The agglutination of single room units to larger structures with a relatively closed front seems to be typical of the traditional core of the village. Passages between the structures are usually narrow; open spaces between the buildings are rare and not larger than $8 \mathrm{~m} \times 8 \mathrm{~m}$. Access to some rooms is apparently only possible through others. As a contrast, buildings in the western part of Maqta are clearly separated from each other and widely spaced. Larger houses have a walled courtyard from which each room is directly accessible.

While the majority of houses is built on a rectangular plan - the model structure is a single room with the door as the sole opening in the longer side-some houses in the eastern part of Maqta are built on an irregular plan, due to their clustering in a restricted area. Walls are built of rubble and mortar, slightly battered, and in some 


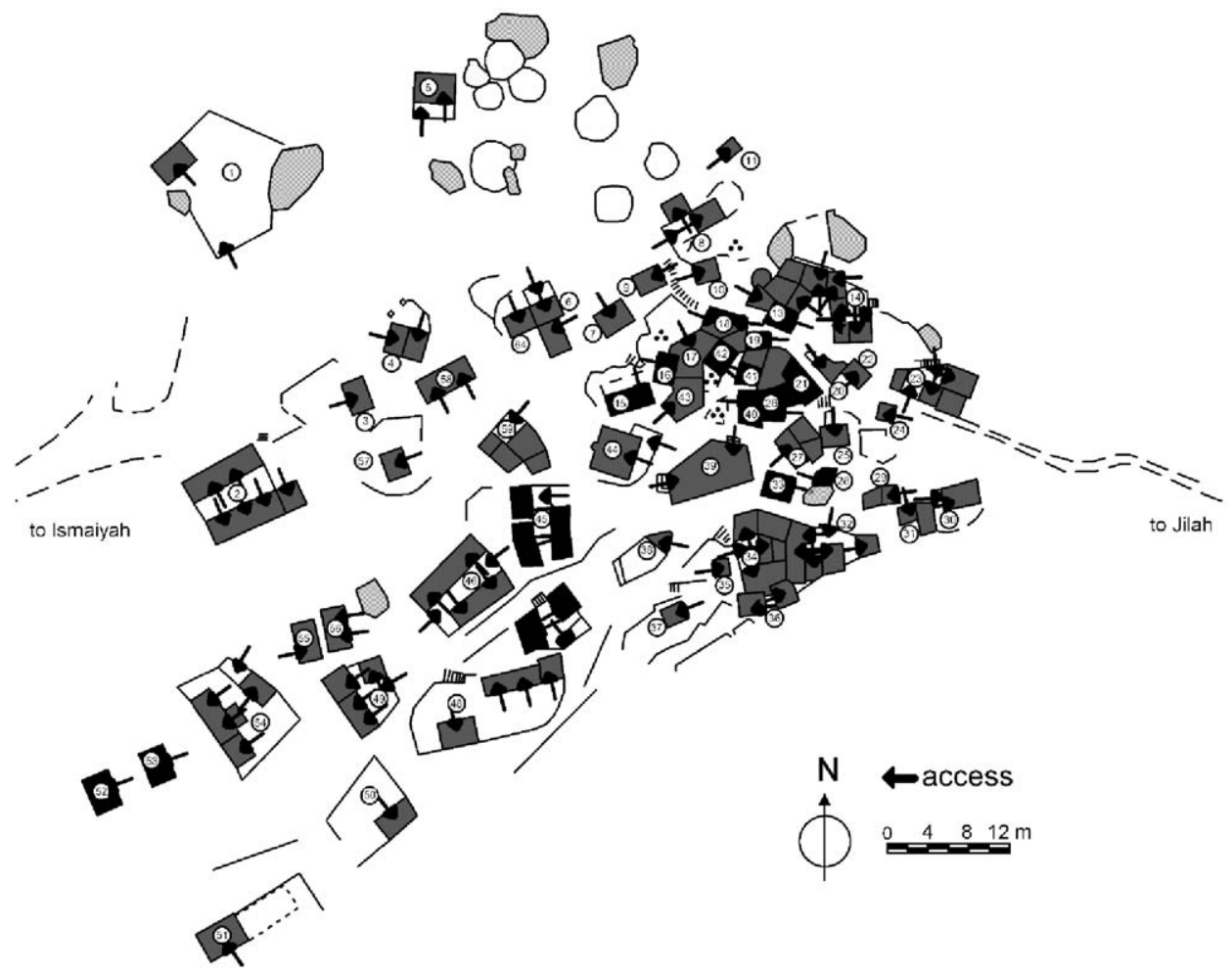

Fig. 5. General plan of the central housing area of Maqta (Oman) with arrows indicating the access to the respective building.

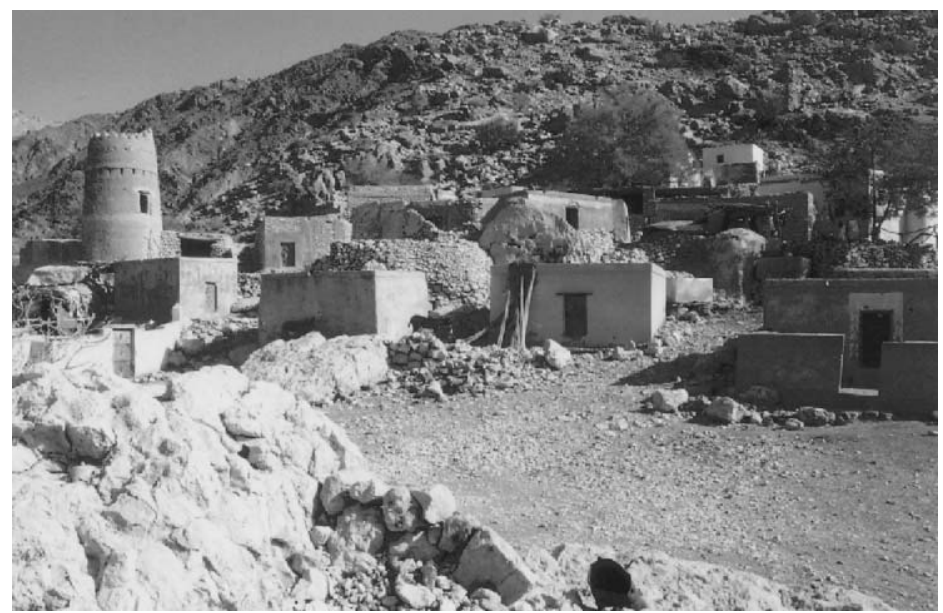

Photo 5. Eastern half of the central housing area of Maqta from NW. 


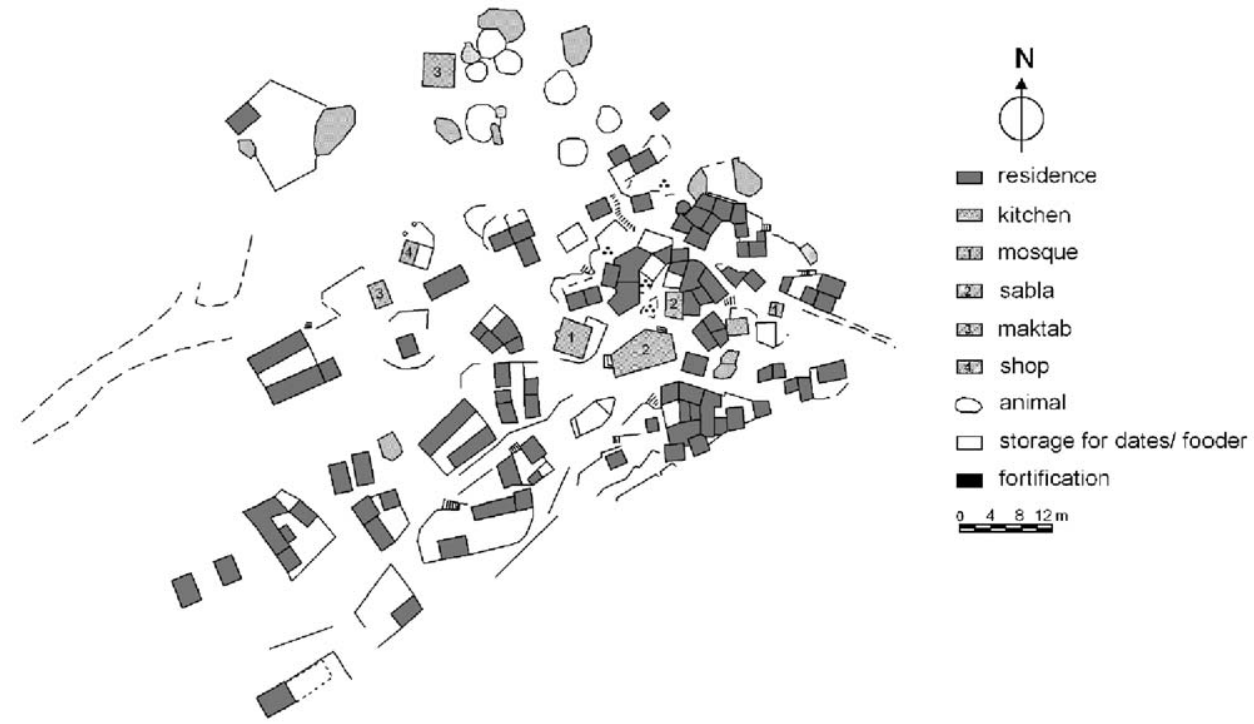

Fig. 6. Plan showing the functions of buildings in the central housing area of Maqta, Oman.

cases plastered and whitewashed. All buildings are single-storey. A cornice made of a horizontal layer of flat stones prevents the water from seeping down the walls. The flat roofs are constructed with beams and layers of mud and pebbles. Cement mortar and cement plastering can be observed on recent buildings, particularly in the western half of the village, whereas no cinder blocks were found yet.

The eastern part of Maqta shows a certain functional variety (Fig. 6). Here, the two mosques of the village are located. A small masjid (24) marks the entrance of the path from the east, whereas the main mosque (44) occupies a central position, easily accessible from both parts of the village, and next to the roofed place for receptions and gatherings of the men (sabla, 39). The closed winter sabla (40) is located on the same square. Further to the north, a watchtower emerges from a cluster of houses (13), offering a view on both paths leading up or down the valley. Some of the rooms of the central cluster (as well as some freestanding buildings) are used as storerooms for dates. No external features mark them off from the residential rooms next door; they could very well have been built as dwellings and then turned into their present function in the recent expansive phase of the village. Other buildings are unoccupied and in a state of decay; some are even completely ruined (Fig. 7).

On the wide square which forms the entrance to Maqta from the direction of Suma'iyah, two buildings (3 and 5) are identified as school (maktab) and the teacher's residence, reportedly built by a private foundation. A shop on the square (4) is presently unoccupied. The general impression of emptiness or depopulation in Maqta is explained by the fact that about half of the houses belong to shepherds who dwell in the mountains for days and weeks. 


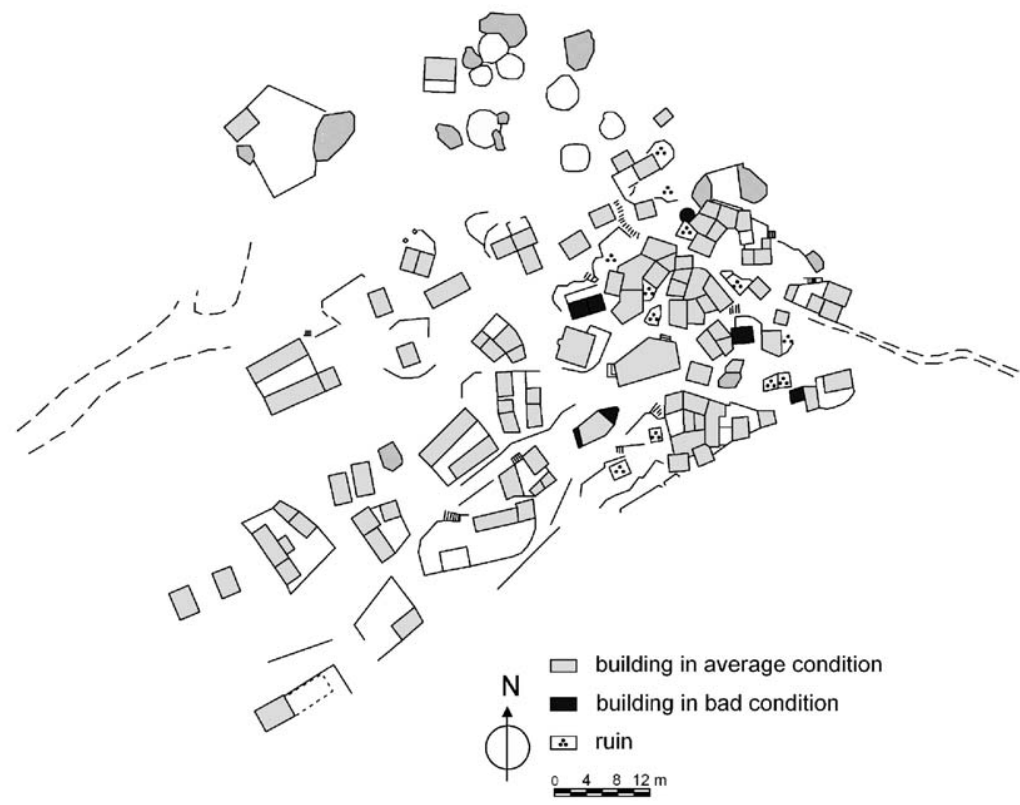

Fig. 7. Plan showing the building conditions of the central housing area of Maqta, Oman.

\subsection{Archaeological setting}

The survey in the surroundings of Maqta did not provide evidence of any settlement older than the existing one. In particular, no traces of the early Iron Age fortress dated by Yule and Weisgerber (1998) without any pottery finds were detected. However, there were numerous remains of burial places from different periods. Two Hafit-type tombs (Maq16 and Maq17), even without finds clearly recognizable by their outstanding position and their building technique, were detected on the slope at the south side of the road at the entrance to the central housing area of Maqta. They are probably identical to Maqt1 of the survey by Yule and Weisgerber (1998). Another Hafit-type tomb (Maq18) is visible on the southern crest of the sedimentation depression above the central housing area of Maqta.

Just below the Hafit tombs at the edge of the depression, there are also some Umm an-Nar tombs (Photo 6) which were described as houses from the same period (Maqt5) by Yule and Weisgerber (1998). The round building Maq3 is constructed with large boulders and an entrance to the south-west. In the center of the building traces of a compartment wall running north-east-south-west are visible which indicates that this building was a tomb rather than a house. The same is true for Maq14 which presumably originally had several chambers. Its southern part is heavily destroyed and it is possible that it was used for burials during later time periods. The constructions Maq4-Maq6, and Maq8 are ringwalls with inserted or attached walls. Due to the pottery found in their surroundings it is very probable 

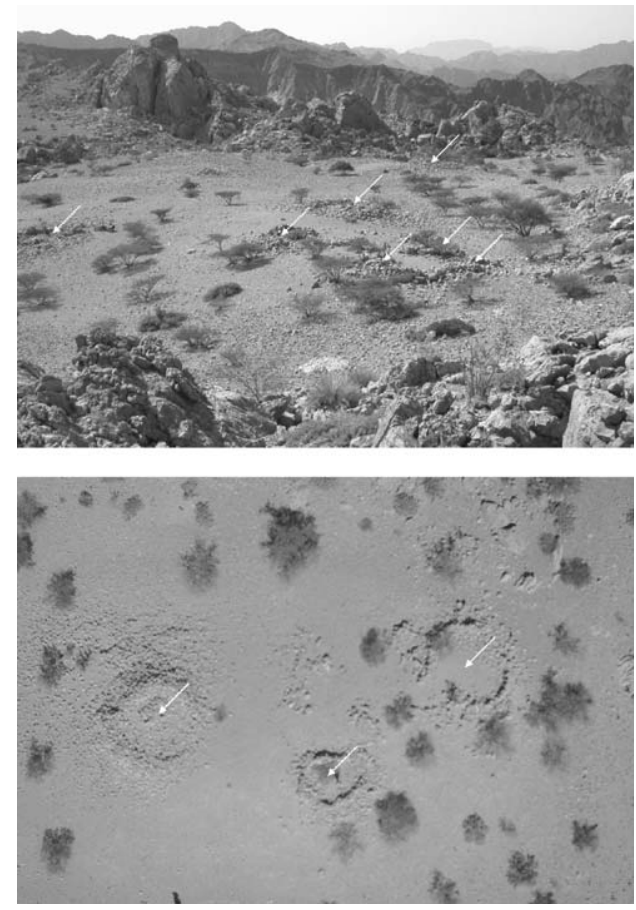

Photo 6. Dilapidated and re-used Umm an-Nar tombs (marked by white arrows) in the sedimentation depression above the oasis of Maqta (above). Aerial view of the dilapidated and re-used Umm an-Nar tombs (marked by white arrows) in the sedimentation caldera above the oasis of Maqta (below).

that they were originally Umm an-Nar tombs and later used for secondary burials. In the Islamic period they may have been used as foundations for houses. A small Islamic cemetery (Maq2) is situated about $50 \mathrm{~m}$ south of the prehistoric tombs. An oval tomb of a double wall of stones and an inner filling of small stones is located between the Islamic graves (Maq1). Such tombs appear frequently on Islamic cemeteries to emphasize the position of a high ranking person. However, on the cemetery there were scattered several early Iron Age sherds which may point to its interpretation as an early Iron Age tomb. Inside the modern settlement no prehistoric or early and middle Islamic pottery was found. Even on the rubbish dump - a very promising location for archaeological finds in most of the Omani oases - no prehistoric pottery was identified.

In spring 2003 about $20 \mathrm{~km}$ south-east of Maqta along the traditional footpath between Jaylah and Mibam 15 new Hafit-type tombs (Jay1-8, Jay12, Jay13, Jay15-19, Jay21) were discovered (Photo 7), however, there are likely more in the surroundings. The largest one, Jay6, has a diameter of $7.5 \mathrm{~m}$ and a height of $2.5 \mathrm{~m}$. Jay16 is the best preserved one with only one cap stone missing. It measures $4.9 \mathrm{~m}$ in diameter and $2.5 \mathrm{~m}$ in height. The other tombs are more or less dilapidated with some being used for later burials. Two very demolished cist graves or wolf traps were 


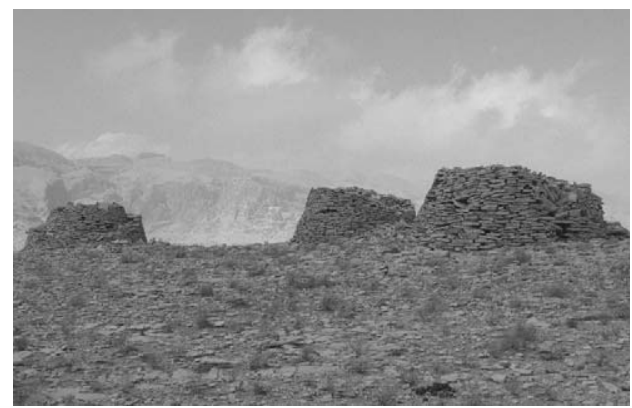

Photo 7. Hafit-type tombs Jay16-Jay18 on the plateau $3 \mathrm{~km}$ from Jaylah.

also found (Jay14, Jay22). Close to construction Jay14 a sherd of the late Iron Age (300 BC-900 AD) was discovered which might prove the use of one or more of these buildings during that period. Jay9-Jay11 were round constructions with a diameter of $2.5 \mathrm{~m}$ and a height of $0.4 \mathrm{~m}$. They could be also tombs but there is no proof for this assumption. Jay20 is a $1.2 \mathrm{~m}$ high construction built of a double-corbelled wall of which the upper part is not closed. Probably, this was also a Hafit tomb, and the outer walls were robbed. A small Islamic cemetery is situated close to Jay7. Reportedly, there also are tombs on the mountain crest above Jaylah; however, their type and position could not be examined. Finally, a series of Hafit-type tombs are situated on prominent locations along Wadi Khabbah that connect the Shir plateau with the inland oasis of ash-Shariq and Suma'iyah.

\section{Discussion}

\subsection{Bio-physical setting and agricultural adaptation}

The extensive network of trade routes probably originating at the ancient, major town of Ibra in the inner-Omani Sharqiya, passing through Suma'iyah and crossing the steep Jabal Bani Jabir towards the port of Tiwi via Maqta underlines the important role the latter village had for inter-ecoregional trade in both directions. This is also reflected by the tribal ties which the inhabitants of Maqta claim to have with the coast rather than the Sharqiya. Beyond that the genetic structure of the traditional wheat germplasm ( $T$. durum, $T$. aestivum and $T$. dicoccon) collected within the Maqta territory and the lower Wadi Khabbah area seems to bear testimony of ancient trade relationships with the Middle East, central Asia and the Indian subcontinent (Al-Maskri et al., 2003; Hammer et al., 2004; Zhang et al., unpublished). In this context Omani mountain oases, even as marginal as Maqta, could well have played the role of hidden refugia for regional gene fluxes that came with trade goods along the coast of the Arabian Sea.

Maqta's role on this trade route was most likely built on its precious supply of water which, however, was much less abundant than that determined in Wadi Tiwi 
on the eastern side of the Shir plateau (Korn et al., 2004) or in oasis systems of the Wadi Bani Awf a watershed on the northern side of the Hajar range of the Jabal Akhdar mountains (Nagieb et al., 2004). The latter systems not only had a larger but also a more consistent flow of spring water during the same drought period which, as indicated by a higher water age, was most likely caused by a larger size of the reservoir in the calcareous bedrock.

Given the scarcity of water in the extremely rugged environment, the agro-pastoral inhabitants of the Maqta territory had to use even minor springs with a flow rate between 5 and $20-1 \mathrm{~h}^{-1}$ dug into small escarpments around which only a few terraces could be built. The ecological setting and the related need for a high reliance on seminomadic herding of small ruminants led to a 'scattered type' rather than a 'core type' of settlement and to the combined cultivation of date palms with wheat. The comparative studies in water-rich environments such as in Wadi Tiwi or the Wadi Bani Awf (Table 3; Korn et al., 2004; Nagieb et al., 2004) provide evidence for the severeness of water scarcity at Maqta even within Oman. In a wider sense, the data also indicate that the more predictable the water availability, the more farmers can rely on perennial date palm cultivation or the combination of date palms and winter plus summer crops. For the inhabitants of Maqta instead, the area dedicated to wheat each year was a function of the springs' flow rate at the onset of the season in fall and the rainfall obtained during the subsequent winter. The data collected in the context of this study show that poor winter rainfall leads to a progressive conversion of wheat fields into areas used for green fodder. First physiological trials under controlled conditions indicated a surprisingly large drought tolerance of the wheat landrace used. This was expressed by its, compared to material from Mongolia and Pakistan, pronounced ability to resume shoot growth once the drought stress is relieved. Wheat yields at Maqta were about half of those measured at Balad Seet which reflects besides the effects of water scarcity mainly the consequences of the very shallow soils (Photo 3) compared to a profile depth of up to $1.3 \mathrm{~m}$ at Balad Seet. For both sites, however, sustainable agricultural production requires the availability of high quality irrigation water from springs, the maintenance of low salt levels in the soil profile by appropriate leaching and the regular application of animal manure to offset the high turnover of organic carbon (Luedeling et al., 2005; Wichern et al., 2004). The apparently recent efforts of production intensification on the sedimentation depression by temporary irrigation and subsequent cultivation of indigo correspond to the recent development of the housing area. They may thus reflect relatively modern efforts of the agropastoralists of the Maqta territory to avoid the consequences of living in a very marginal environment by increasing their income from a flexible mode of agriculture rather than relying on only their herds. The rather late - compared to other oases in Northen Oman - introduction of oasis agriculture around Maqta was also indicated by the results of radiocarbon-dated pollen diagrams obtained from the sedimentation depression above the central housing area. According to these the occurrence of $P$. dactylifera pollen started only sometime after 1500 AD (Urban and Buerkert, unpublished). Interestingly, this was only little before, as shown by the radiocarbon dating of its sarooj cement, the falaj in the sedimentation depression was built, suggesting an intensification of irrigation agriculture. 


\subsection{Architecture}

The structure of the village as well as the distribution of building types clearly indicate that the eastern part of Maqta's central housing area is the traditional core from which the village has grown. Differences in building type and construction technique provide evidence that the western half of the village is of relatively recent date. The area west of the old core offers free space with a relatively low slope, which can be easily terraced through retaining walls. A few houses at the eastern margin of the village $(23,30,31)$ are also of recent construction and seem to form an eastern extension of the settlement on the few spots on the steep slope where buildings can be established. Apparently, expansion to hitherto little used ground has made it possible for some inhabitants of Maqta to leave the central housing area. This might explain the rededication of centrally located houses as storage buildings. A future expansion of this area would only be practicable to the west, but will be generally hampered by the rugged topography.

\subsection{Archaeology}

The results of the survey in the surroundings of Maqta strongly suggest that there was no permanent settlement in the village territory until the late Islamic period. This likely reflects the relative unreliability of the spring outflow in an environment with reportedly up to 7 years of drought.

This distinguishes the scattered oasis of Maqta considerably from the core oasis of Balad Seet in the northern Hajar mountains where the springs provided abundant water even after a prolonged period of drought and where thus likely the cause for a continued settlement since the early Iron Age (1000-600 BC) (Häser, 2000, 2003; Nagieb et al., 2004).

Nevertheless Maqta was, together with Habaynah, Jaylah and Al Ghayl, one of the very few places on the Shir plateau where water was available year-round. This should have been attractive to pastoralists at least since the late 4th or early 3rd millennium BC. An additional reason which may have made the Maqta territory attractive to a semi-nomadic population was the sedimentation depression above the central housing area which as in modern times has provided decent grazing conditions to small ruminants and donkeys for a few weeks after one of the scarce but heavy rainfall events. Even though the scarceness of tombs in its proximity indicates, that Maqta remained an inhospitable environment.

It is thus unlikely that Maqta has played a major role as an oasis settlement for a sedentary or larger pastoral population during the 3rd millennium BC when the famous tower tombs and the Hafit-type tombs were built on top of the Shir plateau and as indicated by the few climate records available for this period the vegetation was very much alike today's (Urban and Buerkert, unpublished). These structures could be markers for main trading routes between the coast and the inland. This interpretation is strengthened by the recently discovered tombs at Tiwi, those between Mibam and Jaylah and those at Jaylah itself. They find their counterparts on the south-eastern side of the Hajar mountains along Wadi Khabbah, at Suma'iyah and at Ibra.

These occurrences of Hafit-type tombs along major routes is not singular in this region but a recurrent phenomenon all over the Arabian Peninsula. This shows that 
the Hafit-type tombs on the Shir plateau are part of a network and as such are not that exceptional as postulated when they were first discovered. Nevertheless, the tower tombs have to been regarded as rather special, since for the time being they have no real comparison. Additionally to their use as graves and possibly as signs for trading and pastoral routes, they could well have been monumental markers indicating the occurrence of four water-rich wadis in a xeric environment. However, until a complete ground survey of the surrounding mountains has been completed, this function will remain somewhat speculative as it is more likely to discover tower tombs near settlements or trade routes than elsewhere. A former ritual function of these tombs for people living in the catchment area of the wadis cannot be excluded either.

\section{Conclusions}

As a scattered agro-pastoral settlement with a recently built central housing area, a large number of tiny terrace systems cultivated with date palms and a flexible area of wheat irrigated for a few months, the Maqta territory represents an extreme case of human adaptation to a xeric mountain environment in Northern Oman. Compared to other oasis systems in the Hajar range, at Maqta agriculture based on the use of aini-aflaj-conveyed spring water may have been developed only after 1500 AD and thus be relatively recent. Nevertheless, the permanent availability of spring water in this life-threatening desert should always have made Maqta an important resting place for nomads and their herds. As such, its existence also must have been instrumental in developing the millennia-old network of trade and pastoral routes from the Omani coast to the inland which gave rise to the tower tombs on top of the Shir plateau whose mysterious, possibly multiple role remains to be unravelled.

\section{Acknowledgements}

The authors would like to thank Eike Luedeling, Werner Aeschbach-Hertig, Horst Weier and Matthias Brommer for their contribution to the water measurements, the hydro-geological characterization of the study area and the digitizing of maps. They are also indebted to Juergen Schreiber for his contribution to the archaeological survey and classification of pottery, to Andreas Fein for the drawing of the architectural plans, to Rashid bin Ahmad Al-Uwaysi and the farmers of Maqta for their help and patience, to Sultan Qaboos University at Muscat for infrastructural support and to the Deutsche Forschungsgemeinschaft (DFG) and the German Archaeological Institute (DAI) for funding.

\section{References}

Aeschbach-Hertig, W., Schlosser, P., Stute, M., Simpson, H.J., Ludin, A., Clark, J.F., 1998. A ${ }^{3}$ H/ ${ }^{3}$ He study of groundwater flow in a fractured bedrock aquifer. Ground Water 36, 661-670. 
Al-Maskri, M., Nagieb, M., Hammer, K., Filatenko, A.A., Khan, I., Buerkert, A., 2003. A note about Triticum in Oman. Genetic Resources and Crop Evolution 50, 83-87.

Beyerle, U., Aeschbach-Hertig, W., Hofer, M., Imboden, D.M., Baur, H., Kipfer, R., 1999. Infiltration of river water to a shallow aquifer investigated with ${ }^{3} \mathrm{H} /{ }^{3} \mathrm{He}$, noble gases and CFCs. Journal of Hydrology 220, 169-185.

Biagi, P., 1988. Surveys along the Oman Coast: preliminary report on the 1985-1988 campaigns. East and West 38, 271-291.

Buerkert, A., Mahler, F., Marschner, H., 1996. Soil productivity management and plant growth in the Sahel: potential of an aerial monitoring technique. Plant and Soil 180, 29-38.

FAO, 2001. FAOCLIM2 Worldwide Agroclimatic Data Base. FAO, Rome, Italy.

FAO Stat., 2003. FAO, Rome, Italy, http://apps.fao.org/page/collections?subset = agriculture, 10/05/2003

George, M.R., 1987. Planning guide no. 4. Rangeland Watershed Program, University of California, Davis, USA, http://agronomy.ucdavis.edu/calrng/planning_guide_pdf/PG4.pdf, 10/05/2003.

Hähnel, W., 1961. Die Lackfilmmethode zur Konservierung geologischer Objekte. Der Präparator. Zeitschrift für Museumstechnik 7 (4), 243-263.

Hammer, K., Filatenko, A.A., Alkhanjari, S., Al-Maskri, A., Buerkert, A., 2004. Emmer (Triticum dicoccon Schrank) in Oman. Genetic Resources and Crop Evolution 51, 111-113.

Häser, J., 2000. Formation and transformation processes of oasis settlements in the Sultanate of Oman: preliminary report on a new field project. Proceedings of the Seminar for Arabian Studies 30, 115-118.

Häser, J., 2003. Results of a survey in Wadi Bani Awf and the al-Hamra region. Proceedings of the Seminar for Arabian Studies 33, 21-30.

Häser, J., Schreiber, J., 2003. Ein früheisenzeitliches Pyramidensiegel aus Oman. Baghdader Mitteilungen $34,205-219$.

Ibrahim, M., ElMahi, A.T., 2000. A Survey between Quriyat and Sur in the Sultanate of Oman (1997). Proceedings of the Seminar for Arabian Studies 30, 119-136.

Korn, L., Häser, J., Schreiber, J., Gangler, A., Nagieb, M., Siebert, S., Buerkert, A., 2004. Tiwi and Wadi Tiwi: the development of an oasis on the north-eastern Coast of Oman. Journal of Oman Studies 13, $57-90$.

Luedeling, E., Nagieb, M., Wichern, F., Brandt, M., Deurer, M., Buerkert, A., 2005. Irrigation of manmade terrace soils in a mountain oasis of northern Oman. Geoderma 125, in press.

Nagieb, M., Häser, J., Siebert, S., Buerkert, A., 2004. Agriculture, hydro-infrastructural conditions and settlement history of a mountain oasis in Northern Oman. Die Erde, in press.

Schreiber, J., Häser, J., 2004. Archaeological survey at Tiwi and its hinderland (Central Oman). Proceedings of the Seminar for Arabian Studies 34, 319-329.

Wichern, F., Luedeling, E., Müller, T., Joergensen, R.G., Buerkert, A., 2004. Field measurements of the $\mathrm{CO}_{2}$ evolution rate under different crops during an irrigation cycle in a mountain oasis of Oman. Applied Soil Ecology 25, 85-91.

Yule, P., 1992. Neue archäologische Entdeckungen am Persisch-Arabischen Golf. Antike Welt 23 (4), 274-279.

Yule, P., Weisgerber, G., 1996. Die 14. Deutsche Archäologische Oman-Expedition 1995. Mitteilungen der Deutschen Orient-Gesellschaft 128, 135-155.

Yule, P., Weisgerber, G., 1998. Prehistoric tower tombs at Shir/Jaylah, Sultanate of Oman. Beiträge zur Allgemeinen und Vergleichenden Archäologie 18, 183-241. 